\title{
Çevresel Maliyetlerin Faaliyet Tabanlı Maliyetleme Yöntemi ile Belirlenmesi ve Bir Uygulama
}

\author{
Ayşe KURTLU*
}

\begin{abstract}
$\ddot{O} Z$
Serbest mal olarak görülen çevre, bugün çevresel sorunların artmastyla birlikte ekonomik bir mal olarak görülmeye başlanmıştır. Çevrenin aşırı kullanımı kendini yenileme kapasitesini aşınca çevresel sorunlar ortaya çıkmıştır. 1970'li yıllardan beri artarak devam eden çevre sorunları canlı yaşamı tehdit eder boyutlara ulaşmış ve çevre sorunlarının nedenleri ve çözüm yöntemleri önemli hale gelmiştir. Bu yöntemlerden biri, çevresel maliyetleri minimize eden, olumsuz çevresel etkileri azaltan ve çevresel maliyet bilgilerini karar alma sürecinde kullanılmak üzere yönetime sunan çevre muhasebesidir. Bu çerçevede çevresel maliyet muhasebesi ve faaliyet tabanl maliyetleme yöntemleri entegre edilerek, genel üretim giderleri içerisinde kaybolan çevresel maliyetlerin neden sonuç ilişkisi kurularak sinıflandırılması, toplam maliyetler içindeki payının açık bir şekilde belirlenmesi ve böylece işletmelerin çevreye verdiği zararların minimize edilerek maliyet etkinliğinin sağlanması araştırmanın amacını oluşturmaktadır.
\end{abstract}

Anahtar Kelimeler: Çevre Muhasebesi, Çevresel Maliyet Muhasebesi, Faaliyet Tabanlı Maliyetleme, Cam Üretim İşletmesi

JEL Sinıflandırması: M41, M49, D20

\section{Determination of Environmental Costs by Activity Based Costing Method and An Application}

\section{ABSTRACT}

Previously, the environment was seen as free good, began to be seen as an economic good with the increase of environmental problems. Excessive use of the environment, when exceeded selfrenewal capacity have emerged environmental problems. Enviromental problems that continuing increase since 1970's has reached threatens to live life and has become important causes and solutions of the environmental problems. One of these methods is environmental accounting. Its main function is to minimize the environmental cost, to reduce the negative environmental impacts and to provide the environmental cost informations to the management in decision-making process. The purpose of this study, with integrating environmental cost accounting and activity-based costing methods, is to classify the environmental costs lost in the overall production costs, by relating cause effect relationship, to clearly determine its share in total costs and to provide cost effectiveness by minimizing demage to the environment caused by enterprises.

Keywords: Environmental Accounting, Environmental Cost Accounting, Activity Based Costing, Glass Production Enterprise

JEL Classification: M41, M49, D20

\section{GíRiş}

Canlı varlıklar için vazgeçilmez bir unsur olan çevre ve çevresel kaynaklar, canlılar tarafından yıllardır kullanılmaktadır. Biyolojik çevre yiyecek, giyecek ve barınma ihtiyaçlarını karşılarken; fiziksel çevre maden vb. kaynakları

\footnotetext{
* Yrd. Doç. Dr., Karabük Üniversitesi Safranbolu Turizm Fakültesi, Turizm Rehberliği Bölümü. ayseergul@karabuk.edu.tr
} 
karşılamaktadır. Ancak çevresel kaynaklar sınırsız değildir ve aşırı tüketilmesi çevrenin dengesini bozmaktadır (Okutmuş, 2005: 9). Hem çevrenin serbest mal olmaktan çıkarak ekonomik bir mal olarak görülmesi, hem işletmelerin uzun vadede kar sağlayabilmek için çevreye duydukları ihtiyaç, hem de toplum ve tüketici baskıları, çevre ile ilgili çeşitli organizasyonlar ve yasal düzenlemeleri de beraberinde getirmiştir (Haftacı ve Soylu, 2008: 93).

Küreselleşme, sanayileşme ve teknolojik gelişmelerle üretim ve tüketimin artması, doğal kaynakların tükenmesine ve çevrenin büyük ölçüde zarar görmesine neden olmuştur. Küresel 1sınma, ozon tabakasının incelmesi, hayvan ve bitki çeşitliliğinin giderek azalması, hava, su, toprak kirliliğinin giderek artan olumsuz sonuçları gibi çevresel sorunların artması, tüm dünyada çevresel sorunlara çözüm arayışını hızlandırmıştır (Kırlığlu ve Zeytin, 2015: 754). Bu temelde çevre ile ilgili ilk çalışmalar 70'lerde Birleşmiş Milletler (BM) ve Gümrük Tarifeleri ve Ticaret Genel Anlaşmaları (GATT) ile başlamış, Kopenhag, Basel, Montreal, Kyoto, Havana protokolleri vb. ile devam etmiştir (Okutmuş, 2005: 2).

Çevre ile ilgili kaynaklar işletmelerin üretim girdisini oluşturmakta ve üretim sürecinin sonunda birtakım artıklar ortaya çıkmaktadır. İşletmelerin faaliyetleri sonucu oluşan çevre kirliliğinin ve çevreye verdiği zararın, işletmelerce bilinmesi ve giderilmesi gerekmektedir (Okutmuş, 2005: 3). Başka bir deyişle işletmelerin üretim süreci sonunda meydana gelen çevresel etkilerin parasal boyutlarının belirlenmesi, ölçülmesi ve muhasebe sistemi içerisinde değerlendirilmesi için çevresel faaliyetlerle ilgili verileri sağlayacak yöntemlerin geliştirilmesi gerekmektedir (Haftacı ve Soylu, 2008: 93). Bu kapsamda işletmelerin, daha yaşanabilir ve temiz bir çevre için önemli sorumluluklar üstlenmesinde, sorumlulukların uygulanmasinda ve denetlenmesinde kullanabilecekleri önemli araçlardan biri çevre muhasebesidir (K1rlıoğlu ve Fidan, 2010: 3).

Çevre muhasebesi, fiziksel ölçüler, hammadde ve enerji tüketimi, enerji akışları, atıkların yok edilmesi, çevresel maliyetler, maliyet tasarrufları ve olası çevresel etkilerle ilgili bir muhasebe türü olarak tanımlanmaktadır (Jasch, 2003: 668). Finansal muhasebe bilanço ve gelir tablosunu kapsarken, çevre muhasebesi çevresel etkilerin maliyetleri ve çevresel sorumlulukların ilgililere sunulmasını kapsamaktadır. Finansal muhasebe veri oluşturur, yönetim muhasebesi veriyi işleyerek bilgiye dönüştürür; çevre muhasebesi ise çevresel maliyetlerin belirlenerek ürünlere dağıtılmasını ve çevresel maliyetler ile ilgili bilgilerin karar alma sürecinde kullanılmasını sağlamaktadır (EPA, 1995: 4-6).

İlgili literatür incelendiğinde, özellikle Türkçe literatürde çevresel maliyet muhasebesi, genel olarak çevre muhasebesi (Aydın, 2012; Başkale, 2009; Çelik, 2007; Çetin, Özcan ve Yücel, 2004; Haftacı ve Soylu, 2008; Okutmuş, 2005) ana başlığı adı altında incelenmiş ve çoğunlukla teorik olarak çalışılmıştır.

Çevresel maliyetlerin modern maliyet yöntemleri ya da faaliyet tabanlı maliyetleme yöntemi ile belirlenmesine yönelik çok fazla çalışma bulunmamaktadır. Çevresel maliyetlerin belirlenmesine yönelik yapılan 
çalışmalar ise daha çok çevresel maliyetlerin muhasebeleştirilmesi üzerine yoğunlaşmıştır. Örneğin; Çalış (2013) çalışmasında çevresel maliyetlerin muhasebeleştirilmesinde örnek uygulamalara yer vermiştir. Ergin ve Okutmuş (2007) çalışmalarında çevresel maliyetlerin tekdüzen hesap planı çerçevesinde muhasebeleştirilmesini incelemiştir. Gönen ve Güven (2014) çalışmalarında çevresel maliyetlerin tekdüzen muhasebe sistemi ve hesap planına göre muhasebeleştirilmesi incelemiştir. Benzer şekilde Kırlığlu ve Fidan (2011) çalışmalarında KOBİ'lerin çevresel maliyetleriyle ilgili durumlarını ve farklılıklarını ortaya koymuşlardır.

Çevresel maliyetlerin geleneksel maliyet yöntemleriyle saptanması, ayrı bir sınıflandırmaya tabi tutulmaması, neden sonuç ilişkisi kurulmadan genel üretim giderleri içerisinde değerlendirilmesi özellikle çevreden daha fazla yararlanan işletmelerde çevresel maliyetlerin kontrol altına alınmasını engellemektedir. $\mathrm{Bu}$ bakımdan çalışmada, çevresel maliyetlerin, genel üretim giderlerinin daha doğru dağıtılmasını amaçlayan faaliyet tabanlı maliyetleme yöntemiyle sınıflandırılması, belirlenmesi, ayrı bir unsur olarak değerlendirilmesi ve minimize edilerek kontrol altına alınmasını belirlemek amacıyla Akdeniz Bölgesinde faaliyet gösteren bir ısıcam üretim işletmesinde örnek olay çalışması yapılmıştır.

\section{I.ÇEVRE MUHASEBESİ}

Birleşmiş Milletler tarafından 1992'de düzenlenen konferansta çevrenin zarar görmesinin başlıca nedeninin sanayileşmiş ülkelerdeki sürdürülemez tüketim ve üretim biçimi olduğu doğrulanmıştır. Sanayileşmiş ülkelerdeki çevre kirliliği, çevre ile ilgili değer yargılarını değiştirmiş, çevrenin de zaman içinde kirlenerek tükenebilen bir kaynak olduğu ve bunun bir maliyetinin olduğu şeklinde bir yargıya dönüşmüştür (Çelik, 2007: 151; Kırlığlu ve Can, 2006: 4243). Çevre ile ilgili yasal düzenlemeler, çeşitli organizasyonların faaliyetleri, toplum baskısı ve tüketicilerin tepkisi, işletmeleri çevre ile ilgili konularda duyarlı davranmaya ve karar alma sürecinde çevre unsurlarını dikkate almaya zorlamaktadır (Gönen ve Güven, 2014: 40; Haftac1 ve Soylu, 2008).

Çevre kirliliğinin tehlikeli boyutlara ulaşması ve bu bakımdan bilinç düzeyinin giderek artması sonucu işletmeler de çevre konusunda daha duyarlı davranmak ve çevresel maliyetleri de daha doğru hesaplamak zorunda kalmışlardır (Çetin vd., 2004: 62). Bu çerçevede çevre muhasebesi kavramının ortaya çıkması ve çevresel maliyetlerin hesaplanması ile çevreye verilen zararın canlılar üzerine olumsuz etkileri ve gelecekte yaratacağ 1 olumsuzluklar net bir şekilde görülmüş ve bu konuda, ülkeler, organizasyonlar, işletmeler daha duyarlı olmaya başlamıştır (Haftacı ve Soylu, 2007: 112; Yereli ve Yakın, 2009: 70).

Küreselleşme, küresel rekabetin artması ve teknolojik gelişmeler çevre ve çevre kirliliği konusunda bilinç düzeyini artırırken karlılık, maliyet minimizasyonu, iyileştirme, gelişme gibi işletme hedeflerinin yanına çevrenin korunması ile ilgili hedefleri de beraberinde getirmiştir. Bugün, işletmelerin mali durumları ile ilgili gruplara mali konuların yanı sıra çevre ile ilgili konularda da bilgi sağlaması beklenmektedir. Bu beklentiler sonucunda çevre muhasebesi geniş anlamda uygulama alanı bulmuştur (Alagöz, 2012: 55; Aydın, 2012: 100). 
İşletmelerin faaliyetleri sonucu çevrede ortaya çıkan niteliksel ve niceliksel olumsuzlukların belirlenmesi ve bunların fiziksel ve parasal değerlerinin belirlenmesi ve izlenmesi çevre muhasebesi ile mümkün olmaktadır (Çalış, 2013: 176). Çevre muhasebesi ile ilgili yapılan araştırmalarda, tanım üzerinde bir fikir birliği bulunmamaktadır. Tanımların, çoğunlukla finansal muhasebe, çevresel maliyetler ve çevresel denetim perspektifinden ele alındığı görülmektedir (Haftacı ve Soylu, 2007: 114). Buna göre; çevre muhasebesi ya da çevresel muhasebe, işletmenin çevrede yarattı̆̆ olumsuz etkilerin finansal ve finansal olmayan yönlerinin ölçülmesi ve muhasebe kayıtlarının yapılması şeklinde tanımlanmaktadır (Beer ve Friend, 2006: 2; Okutmuş, 2005: 42; Yereli ve Yakın, 2009: 70). Çevre muhasebesi, çevre koruma masrafları gibi çevre ile ilgili faaliyetlerin parasal etkilerini inceleyen bir muhasebe yaklaşımıdır (Gönen ve Güven, 2014: 43; Jachnik, 2006, 14). Çevre muhasebesi, çevreyle ilgili mali nitelikli işlemlerin anlamlı ve doğru bilgiler sağlayacak şekilde gerekli kaynakların toplanması, doğruluklarının tespit edilmesi, kaydedilmesi, raporlanması, analiz edilmesi ve yorumlanması şeklinde tanımlanabilir. Yeni bir muhasebe türü olmayıp, çevresel varlıkların değerlendirildiği bir bilgi sistemidir (Haftac1 ve Soylu, 2007: 115; Kırlığlu ve Yıldız, 2004: 52).

Yukarıda yapılan tanımlarda da görüldüğü üzere; çevre muhasebesi kavramının oldukça geniş ve zor bir konu olduğu görülmektedir. Bu kapsamda çevre muhasebesi ile ilgili yapılan açıklamaların hangi açıdan ele alındığı büyük önem taşımaktadır. Nitekim, kavramın, genel anlamda literatürde küresel (makro), ulusal ve işletme (mikro) olmak üzere üç farklı boyutta ele alındığı görülmektedir (EPA, 1995: 4; Kırlığlu ve Can, 2006: 6). Küresel ve ulusal boyutta çevre muhasebesi makro iktisat içinde ele alınmaktadır. İşletme boyutunda ise çevre muhasebesi, işletmelerin muhasebe sistemi içinde değerlendirilmektedir (Kırlığlu ve Yıldız, 2004: 52; Okutmuş, 2005: 43; Yereli ve Yakın, 2009: 71). Dolayısıyla bu çalışmada çevre muhasebesi uygulamaları mikro boyutta ele alınmıştır.

İşletme boyutunda muhasebe sistemleri içerisinde değerlendirilen çevre muhasebesi, finansal, maliyet ve yönetim muhasebesi açısından olmak üzere üç farklı şekilde ele alınmaktadır (Kırlığlu ve Can, 2006: 6). Buna göre; finansal muhasebe açısından çevre muhasebesi, çevresel etkilerin muhasebeleştirilmesini ifade ederken; maliyet muhasebesi açısından çevresel performans, kontrol maliyetleri, çevre dostu ürün ve üretim süreci geliştirme, ürün yaşam döneminin uzatılması, ürün karması ve fiyatlama gibi konularda maliyet bilgilerinin edinilmesi ve denetlenmesi anlamına gelmektedir. Yönetim muhasebesi açısından ise çevresel maliyetler ile ilgili bilgilerin karar alma sürecine raporlanmasını ifade etmektedir (Okutmuş, 2005: 52)

\section{II. ÇEVRESEL MALIYETLER}

IASC (Uluslararası Muhasebe Standartları Komitesi) çevresel maliyetleri, "bir işletmenin faaliyetlerini, çevresel etkilerini, yönetim için gerekli çabaların maliyetlerini kapsar" olarak tanımlamaktadır (Çalış, 2013: 181). Çevresel maliyetler, çevreyi koruma, yaşam alanlarını çevre kirliliğinin olumsuz 
etkilerinden arındırma, işletme faaliyetleri sonucu çevrede oluşan olumsuzlukları yok etmek için yapılan harcamalar olarak tanımlanmaktadır (Okutmuş, 2005: 61). Çevresel maliyet muhasebesinde çıktı ile ilgili katı atık, sıvı atık, emisyon gibi maliyetler, bu maliyetlere neden olan girdilere doğru bir şekilde yüklenmektedir (Çelik, 2007: 156).

Çevresel maliyetler ikiye ayrılarak incelenmektedir: Bunlardan ilki işletmelerin sorumlu tutulamadığ 1 sosyal (dışsal) maliyetler (Kırlıoğlu ve Fidan, 2010: 5), ikincisi ise işletmelerin karlılı̆̆ını etkileyen özel (içsel) maliyetlerdir (Beer ve Friend, 2006: 550; Çetin, 2011: 40; EPA,1995: 1).

\section{A. Sosyal Maliyetler:}

Sosyal maliyetler, işletmelerin yasal olarak sorumlu tutulamadığı çevresel bozulma maliyetleridir ve telafi edilemeyecek olumsuz etkilerden oluşmaktadır (Beer ve Friend, 2006: 550; Lazol vd., 2008:63). Çevre muhasebesinin en temel amacı ise sosyal maliyetlerin özel maliyetlere dönüştürülerek maliyet hesaplarına dâhil edilmesini sağlamaktır (Çetin, 2011: 42; Hiçyorulmaz, 2015: 56; Eagan ve Jores, 2002: 77; Kırlığlu ve Fidan, 2010: 6-7).

Sosyal maliyetler kendi içinde azalma/önleme, kullanma ve zarar maliyetleri olmak üzere üçe ayrılmaktadır (Kırlığlu ve Fidan, 2010: 7; Okutmuş, 2005: 94). Buna göre; Azaltma/Önleme Maliyetleri, işletmelerin faaliyetleri nedeniyle neden olduğu çevre kirliği ve sorunlarını ortadan kaldırmak ve azaltmak için katlandıkları maliyetler olarak ifade edilmektedir (Bakkal, 2014: 12; Ergin ve Okutmuş, 2007:149). Çevre planlaması, süreç kontrolü, emisyon ölçüm cihazları, çevreye dostu ürün geliştirme, geri dönüşüm, çevre dostu ambalaj tasarımı, çevre geliştirme, çevresel eğitim, çevre raporları, çevre etiketleme, çevre güvenilirlik, çevresel bilgi sistemi, çevre yönetim sistemi, çevre denetimi, çevre el kitabı, atık kontrolü, atık bertarafı, atık arıtımı ve araştırma geliştirme vb. azaltma maliyetlerine örnek verilebilir (Hiçyorulmaz, 2015: 57).

Kullanma Maliyetleri, işletmeler çevre kaynaklarından genellikle yasal sınırlar içerisinde yararlandıkları için herhangi bir bedel ödememektedir (Ergin ve Okutmuş, 2007:151; Tuğlu, 2010: 60). Hava, su, toprak maliyetleri, gürültü, görüntü maliyetleri, enerji maliyetleri vb. maliyetler kullanma maliyetlerine örnek olarak verilebilir (Başkale, 2009: 48; Hiçyorulmaz, 2015: 57).

Zarar Maliyetleri, hava, su, toprak, fauna, flora kısaca doğaya verilen tüm zararların parasal karşılığ 1 olarak ifade edilmektedir (Ergin ve Okutmuş, 2007:151; Hiçyorulmaz, 2015: 58; K1lı̧, 2008: 32). Zarar maliyetlerinin belirlenebilmesi içinse ölçülebilir unsurların varlıklarının belirlenmesi gerekmektedir. Çevreye yayılan gaz, sebep olunan gürültü vb. durumlar sonucunda olumsuz etkilenen çevresel faktörler için ölçülebilir bir uygulama mümkün görülmemektedir (Çetin, 2011: 44).

İşletmelerin çevreye olumsuz etkilerinin sıfıra indirilebilmesi oldukça güçtür. Bu bakımdan tüm önleme maliyetlerine katlanılarak kullanma maliyetleri sıfıra indirilebilse dahi zarar maliyetleri oluşacaktır. Önleme ve kullanma maliyetleri ne kadar iyileştirilirse zarar maiyetleri de aynı oranda azalacaktır (Okutmuş, 2005: 72). 


\section{B. Özel Maliyetler}

Özel maliyetler, işletmelerin çevreye zarar vermemek ya da vereceği zararı minimuma düşürmek için katlandığı maliyetlerdir. Özel maliyetler de kendi içinde dörde ayrılmaktadır (Hiçyorulmaz, 2015: 59-63):

Geleneksel Maliyetler, sermaye ekipmanı, malzeme, işçilik, hurda değer, binalar gibi işletmelerin süreç, mamul, sistem ve tesisin faaliyet süresi boyunca katlandığı maliyetleri ifade etmektedir.

Gizli Maliyetler, kendi içinde yasal düzenlemelerden kaynaklanan maliyetler, öncül maliyetler, görünmeyen maliyetler ve isteğe bağlı maliyetler olmak üzere dörde ayrılmaktadır. Yasal Düzenlemelerden Kaynaklanan Maliyetler: işletmenin faaliyet gösterdiği ülkenin yasaları gereği katlandığ temizleme, kayıt tutma, açığa çıkarma, etiketleme, hazırlık, koruyucu ekipman, çevresel sigorta, finansal sigorta, kirlilik kontrolü, atık yönetimi, vergiler ve harçlar gibi maliyetlerdir (Hiçyorulmaz, 2015: 59): Özel maliyetleri sosyal maliyetlerden ayırabilmek için işletmenin bulunduğu ülkede uygulanan yasa ve kriterlere bakmak gerekir. Çünkü gelişmiş ülkelerde uygulanan çevre ile ilgili yasalar nedeniyle özel maliyet sayılan bir çevre faktörü gelişmekte olan ülkelerde çevre yasalarının etkin uygulanmamasından dolayı sosyal maliyet sayılabilmektedir (Alagöz, 2012:119). Görülmeyen maliyetler, işletme tesis ya da ürününün yarı ömrüne geldiğinde bunların temizliği, bakımı ya da onarımı sırasında ortaya çıkan maliyetler olarak tanımlanmaktadır (Kırlığlu ve Fidan, 2011:10). İsteğe bağll maliyetler, çevre ile ilgili yasa ve yönetmeliklere uyum için gereken ve işletmelerin gönüllü katlandıkları fizibilite çalışmaları, iyileştirme, geri dönüşüm, çevresel çalışmalar, doğal hayatın ve sulak alanların korunması ve çevresel grup veya araştırmacıların finansal olarak desteklenmesi gibi maliyetlerdir (Hiçyorulmaz, 2015: 62).

Koşullu Maliyetler (şarta bağlı maliyetler), ortaya çıkması kesin olmayan ancak gerçekleşebilir nitelikli bir olaya bağlı olarak gelecekte katlanılacak çevresel maliyetlerdir. Doğal varlıkların zarar görmesi, personel yaralanma zararları, yasal masraflar, doğal kaynak zararları, ekonomik kayıp zararları vb. şarta bağlı maliyetler olarak değerlendirilmektedir.

Imaj ve Çevreyle İlişki Maliyetleri, işletmenin imaj oluşturmak ve dış çevresiyle ilişkilerini devam ettirmek için katlandığı işletme imajı, müşterilerle ilişkiler, yatırımcılarla ilişkiler, sigortacılarla ilişkiler, beyaz yakalı personelle ilişkiler, mavi yakalı personelle ilişkiler, tedarikçilerle ilişkiler, kredi verenlerle ilişkiler, yerel topluluklarla ilişkiler, düzenleyici kişi ya da kurumlarla ilişkiler gibi maliyetlerdir.

Bugün, çevre üzerine olabilecek olumsuz etkileri nedeniyle işletme faaliyetlerinin sikı denetim altında olması gerekse bilinçli tüketicilerden gelebilecek tepkiler işletmelerin, çevre konuşlarında daha duyarlı olmasına neden olmaktadır. İşletmeler üretim faaliyetleri nedeniyle oluşan atıkların çevreyi kirletmemesi için arıtma tesisi, filtre, kanalizasyon, atık depolama alanı vb. yatırımlar yapmakta, çevre dostu ürün üretebilmek için birçok çevresel maliyete katlanmaktadır. Çevresel maliyetler, ürün içinde bulunan hammaddeden çevre 
kirliliği nedeniyle katlanılan ceza ve tazminatlar gibi çok çeşitli olabilmektedir (Okutmuş, 2005: 86).

Çevresel maliyetlerin doğru bir şekilde belirlenebilmesi çevresel etkilerin karmaşık neden ve sonuçlarının dikkate alınmasına bağlı olmaktadır. Çevresel maliyetlerin belirlenmesinde, malzeme ve enerji akımları kaydedilerek gerçek maliyetleriyle değerlenirse çevresel maliyetleme uygun şekilde bu akımların kontrolüne yardım edebilmektedir. $\mathrm{Bu}$ amacı gerçekleştirmek için aşağıda açıklanan beş aşamanın yerine getirilmesi gerekmektedir (Letmathe ve Doost, 2000;426):

- İlk aşamada çevresel etkilerin belirlenmesi gerekmektedir ki bu da ISO 14001 standardının gereksinimlerinden biridir. Genelde, etkilerin çoğunluğu depolama, üretim ve dağıtımı kapsayan malzemelerle ilgilidir. Bu etkilerin nedeni ve çeşidi belgelendirilmelidir. Belgelendirilen etkilerin öneminin yüksek ya da düşük olduğuna karar verilmesi gerekmektedir. Çevresel maliyet muhasebesinde yüksek öneme sahip olanlar değerlendirilmektedir.

- İkinci aşamada malzeme ve enerji akımlarının çevresel etkileri belirlenmektedir.

- Üçüncü aşamada malzeme ve enerji akımlarını kontrol etmek amacıyla gerçek hacimleri ile standart miktarları karşılaştırılmaktadır. Çevresel maliyetlerin hesaplanabilmesi için malzeme ve enerjinin miktarlarının belirlenmesi gerekmektedir.

- Dördüncü aşamada, miktarları hesaplanan malzeme ve enerjinin gerçek maliyetleri değerlendirilmektedir.

- Son aşama ise çevresel maliyetleri bu maliyetlere neden olan girdi, süreç ve ürünlere doğru yüklemektir. Bu aşama, üçüncü aşamada belirlenen malzeme ve enerji etkilerine göre gerçekleştirilmektedir. Malzeme ve enerjinin miktarının belirlenmesi, çevresel etkilerinin tanımlanması ve sistematik olarak girdilere, süreçlere ve ürünlere yüklemek amaçlanmaktadır. Bu durum yalnızca çevresel etkileri azaltmak için değil aynı zamanda yüksek maliyetlere yol açan verimsizlikleri ortadan kaldırmak için de kullanılmaktadır.

\section{III. ÇEVRESEL MALIYET MUHASEBESI VE FAALIYYT TABANLI MALIYETLEME YÖNTEMI}

Çevresel maliyetlerin, geleneksel maliyet muhasebesi yöntemleriyle maliyet merkezlerine gelişi güzel yüklenmesi, işletmelerin olumsuz çevresel etkilerini ve bunun maliyetlerini azaltmak gibi bir amaç içermemektedir (Letmathe ve Doost, 2000;425). Geleneksel maliyet muhasebesinde dişa yayılan gazlar, çıkarılan atıklar, atık su maliyetleri gibi çevresel maliyetler genel üretim gideri olarak değerlendirilmekte, ilk çıktığı yere bakılmaksızın gelişi güzel çeşitli maliyet merkezlerine dağıtılmakta ve hatta üretim sürecinde ortaya çıkan emisyon, atık, israf edilen malzeme maliyetleri gibi maliyetler gizli olmaları ya da kaydedilmemeleri sonucu dikkate alınmamaktadır (Gale, 2005;1). Çevresel maliyetlerin, işletmenin diğer maliyet grupları içinde yer alması, ayrı bir sınıflandırma yapılmaması muhasebenin temel kavramlarından tam açıklama kavramına uymamaktadır (Çalış, 2013: 184; Okutmuş, 2005: 62). Çevresel 
maliyetlerin doğru bir şekilde hesaplanabilmesi için çevresel etkilerin neden ve sonuçlarının dikkate alınması gerekmektedir (Letmathe ve Doost, 2000: 426).

İşletmelerin, çevreye olumsuz zararlarını en aza indirmek ve çevresel maliyetleri azalmak için çevresel maliyetleri neden sonuç ilişkisi kurarak ve doğru bir şekilde belirleyerek yüklemeleri gerekmektedir. Ancak, çevresel maliyetlerin geleneksel maliyet yöntemleri ile bir sınıflandırmaya tabi tutulmadan, neden sonuç ilişkisine bakılmaksızın genel üretim giderleri içerisinde ürünlere yüklenmesi olumsuz etkilerinin net bir şekilde görülememesine neden olmaktadır. Ayrıca, çevresel maliyetlerin geleneksel yöntemlere göre belirlenmesi ve yüklenmesi, yöneticilerin karar alma sürecine katkı sağlamayacaktır.

Modern maliyet yöntemlerinden değer analizi ya da bu yöntemin gelişmiş bir versiyonu olan hedef maliyetleme yöntemi kullanılarak çevresel maliyetler ürün tasarım aşamasına geçmeden önce belirlenebilir ve kontrol altına alınarak azaltılabilir. Ayrıca ürüne değer katan ve katmayan çevresel maliyetler sınıflandırılarak değer katmayan çevresel maliyetler ortadan kaldırılabilir.

Ürün yaşam dönemi maliyetleme yöntemi ile çevresel maliyetlerin belirlenmesinde, bu maliyetlerin ürün yaşam döneminin hangi aşamasında ortaya çıktığı neden sonuç ilişkisi kurularak belirlenebilir. Ürün yaşam döneminin ortaya çıktığı aşamasında önleyici tedbirler alınarak azaltılabilir.

Çevresel maliyetler, kaizen maliyetleme yöntemi kullanılarak da belirlenebilir. Yöntemle belirlenen hedef çevresel maliyetler ile fiili çevresel maliyetler karşılaştırıp, tüm üretim sürecinde değer katan çevresel maliyetler iyileştirilerek değer katmayan çevresel maliyetler ortadan kaldırılabilir.

Çevresel maliyetlerin doğru bir şekilde belirlenebilmesi ve minimize edilebilmesi için bu maliyetleri net bir şekilde sınıflandıran ve toplam maliyetler içindeki payını net bir şekilde gösteren modern maliyet yöntemleri ile birlikte incelenmesi gerekmektedir. Çevresel maliyet muhasebesi ile kullanılabilecek yöntemlerden bir tanesi de faaliyet tabanlı maliyetlemedir.

Faaliyet tabanlı maliyetleme (FTM), endirekt giderlerin belirlenmesinde ve dağıtılmasında, "faaliyetler kaynakları, kaynaklar maliyetleri tüketir" ilkesine dayanan finansal dağıtım anahtarlarının yanında finansal olmayan dağıtım anahtarlarını da kullanan ve müşteriye değer katmayan faaliyetleri elimine etmeyi amaçlayan modern maliyet yöntemlerinden biri olarak tanımlanmaktadır (Ergül, 2014: 15).

FTM yaklaşımı, "maliyet nesneleri faaliyetleri, faaliyetler kaynakları, kaynaklar ise maliyetleri tüketir" prensibine dayanır (Barth vd., 2008: 621). Temelinde yatan düşünce, her bir faaliyetin maliyet birim noktası oluşturularak endirekt maliyetlerin bu noktalarda birleştirilmesi ve dağıtım anahtarları yardımıyla üretim maliyetlerinin ürünlere yüklenmesidir (Hacırüstemoğlu 1995, 316; Wegmann 2009, 7).

İki temel aşamadan oluşan FTM, ilk aşamada tüm faaliyetlerin ve bu faaliyetlerin maliyetlerinin belirlenmesi, ikinci aşamada faaliyet maliyetlerinin ürünlere yüklenmesi gerçekleştirilmektedir. Bu temel iki aşama ise faaliyetlerin belirlenmesi, gruplandırılmas1, maliyet etkenlerinin belirlenmesi, endirekt 
giderlerin faaliyetlere göre dağıtımı (faaliyet maliyetlerinin faaliyet merkezlerinde toplanması) ve faaliyet maliyetlerinin ürünlere yüklenmesi olmak üzere 5 adımda gerçekleştirilmektedir (Erden, 2004:191).

İşletmelerin faaliyetleri nedeniyle ortaya çıkan çevresel maliyetlerin belirlenmesinde, bu maliyetlere faaliyetlerin neden olduğunu savunan FTM yönteminin kullanılması daha sağlıklı sonuçların alınmasına sağlayacaktır. Yöntemin, çevresel maliyetlerin, üretimin hangi aşamasında ortaya çıktığını ve bu maliyetlere hangi faaliyetlerin neden olduğunu daha net bir şekilde göstereceği düşünülmektedir.

FTM, çevresel maliyetlere hangi faaliyetlerin neden olduğunun belirlenmesinin yanı sıra çevresel maliyelerin sınıflandırılmasına, toplam maliyetler içerinde ağırlığının net bir şekilde görülmesine, genel üretim giderleri içerisinde ayrı bir unsur olarak değerlendirilmesine, bir birim ürüne düşen çevresel maliyetlerin hem doğru bir şekilde belirlenmesine hem de yüklenmesine ve böylece çevresel maliyetlerin minimize edilmesine ve karar alma sürecinde etkin bir şekilde kullanılmasına destek olacaktır.

\section{UYGULAMA ${ }^{1}$}

\section{A. İşletmenin Tanıtımı ${ }^{2}$}

Uygulama yapılan işletme $\mathrm{XX}$ tarihinde kurulmuş olup Akdeniz Bölgesinde büyük ölçekli 1sıcam (çift cam) üretimi yapan bir işletmedir. İşletmenin temel alıcıları; oteller, müteahhitler, toptan ve perakende cam işletmeleri ve plastik doğrama üreticileridir. İşletmede 1 sııam dişında vitray, normal cam, ayna, bizuteli cam, rölyefli cam, kumlamalı cam, dekoratif cam vb. cam üretimi yapılmaktadır. İşletme üretim için uygun olan camı $(4 \mathrm{~mm}, 6 \mathrm{~mm}$, $8 \mathrm{~mm}$, buzlu, renkli vb) tedarikçiden temin ederek alıcıların talepleri doğrultusunda üretime sokarak ürünlerini üretmektedir.

İşletme fiili maliyet sistemi kullanmaktadır. İşletmeye ait maliyet verileri işletmede 21 gün çalış1larak derlenmiştir.

\section{B. Üretim Prosesleri}

İşletmede üretim prosesleri aşağıdaki gibidir:

Üretim Planlama: Sipariş ile gelen üretim talepleri işletmeye ulaştığında üretim planlama; miktar, $\mathrm{m}^{2}$, cam tipi vb özellikler dikkate alınarak bilgi işlem ortamına taşınmaktadır.

Kesme: Bilgi işlem ortamına aktarılan üretim emri, kesme bölümüne ulaştıktan sonra üretim planlamanın kısıtlarına uygun olarak kesim işlemi yapılmaktadır.

Montaj: Kesme işlemi makineler ile yapıldıktan sonra camlar, montaj bölümüne aktarılır. Montaj aşaması üç alt aşamadan oluşmaktadır. Öncelikle cam ölçülerine göre alüminyum $\operatorname{ara~çıtalar~}^{3}(25 \mathrm{~mm})$ kesilir. Alüminyum çıtaların içine nem oluşumunu engelleyecek silica-gel maddesi bir makine ile doldurulur ve cama uygun ölçülerde çıtalar birleştirilir. Çıtalar, butly denen çok güçlü bir

\footnotetext{
${ }^{1}$ Alan araştırması yapılan işletmeye ait maliyet verileri 2016 yılı Mayıs ayına aittir.

2 İşletmenin ismi rekabet ve ticari verilerin güvenliği açısından gizli tutulmuştur.

${ }^{3}$ Alüminyum çıtalar iki camı birleştiren ara parçalardır.
} 
yapıştırıcı ile kaplanır. Butyl'in temel özelliği camların çıtaya yapışmasını sağlamaktır. $\mathrm{Bu}$ işlemden sonra saf su ile kesimi yapılmış camlar istenmeyen maddelerden arındırılmak için yıkanır. Isıcamı oluşturacak camlar bir makine vasıtası ile butyl'li alüminyum çıta ile birleştirilir.

İlaçlama: Birleştirilen camların (Isıcam) kenarları ilaçlama bölümünde bir makine aracılığıyla poliüretan madde ile kaplanır ve aralarına birbirine yapışmasını engellemek için mantar konarak kurumaya alınır. Poliüretan maddenin kuruma süresi iklimle değişiklik göstermek kaydıyla 1-2 saat arasıdır.

\section{Cam Üretim İşletmesinde Çevresel Maliyetler}

Alan araştırması yapılan işletme 1sıcam üretimi için gerekli olan camı dışarıdan tedarik etmektedir. Sipariş ile çalışan işletmeye sipariş geldiğinde tedarikçiden gerekli miktarda cam alınarak üretime başlanmaktadır.

İşletmede isıcam üretiminde çevresel maliyetler esas üretim gider yerleri olan kesme, montaj ve ilaçlama gider yerlerinde oluşmaktadır. Camın kesilmesi sırasında ve yapıştırma işlemlerinde 1 sıl işlemler sonucu oluşan hava kirliliği için işletmede baca filtreleri kullanılmaktadır. Kesim ve 1sıl işlemler dışında camın arındırılması için saf su ile temizlenmesi de çevresel maliyet unsuru oluşturmaktadır. $\mathrm{Bu}$ unsur ise çevre vergisi olarak işletmeye yansımaktadır. Isıcam üretiminde kullanılan slica-gel, butly ve poliüretan endirekt madde ve malzemeleri de birer kimyasal olduğu için çalışmada çevresel maliyet olarak değerlendirilmiştir.

Çalışmada çevresel maliyetler faaliyet tabanlı maliyetleme yöntemi ile belirlenmiştir. FTM yönteminde ayrı bir genel üretim gideri unsuru olarak ele alınmıştır. Tablo 1'de işletmenin genel üretim giderleri gösterilmektedir.

Tablo 1: Endirekt Giderlerin Dağılımı

\begin{tabular}{|l|c|}
\hline \multicolumn{2}{|c|}{ Cam Üretim İșletmesine İlişkin Endirekt Giderler } \\
\hline Endirekt İşçilik Giderleri & 105.000 \\
\hline Çevresel Maliyetleri & 928.335 \\
\hline Su Giderleri & 120.000 \\
\hline Elektrik Giderleri & 320.000 \\
\hline Amortisman & 220.000 \\
\hline Toplam Endirekt Maliyetler & 1.693 .335 \\
\hline
\end{tabular}

Tablo 1'de görülen ve toplam tutarı 928.335 TL olan çevresel maliyetlerin içerisinde butly $300.000 \mathrm{TL}$; slica-gel $250.000 \mathrm{TL}$; poliüretan 275.000 TL; temizlik $100.000 \mathrm{TL}$; baca filtrelerinin bakım onarımı aylık 3.000 TL ve çevre vergisi aylık 335 TL'dir.

Alan araştırması yapılan işletmede gerçekleştirilen faaliyetler FTM yöntemine göre dört faaliyet merkezinde toplanmıştır. Tablo 2'de de görüldüğü üzere bu faaliyet merkezleri Faaliyet 1 (F1) sipariş ve kabul faaliyet merkezi; F2 üretim planlama faaliyet merkezi; F3 üretim faaliyet merkezi ve F4 teslimat faaliyet merkezidir. 
Tablo 2: Cam Üretim İşletmesi Faaliyet Merkezleri ve Faaliyetler

\begin{tabular}{|c|c|}
\hline Faaliyet Merkezleri & Gerçekleștirilen Faaliyetler \\
\hline SİPARİŞ VE KABUL (F1) & $\begin{array}{l}\text { - Üretim talebinin gelmesi } \\
\text { - Siparişin miktar, fiyat, kalite ve zaman faktörleri } \\
\text { dikkate alınarak alınması } \\
\text { - Kalınlık, renk, süsleme gibi özel isteklerin } \\
\text { belirlenmesi } \\
\text { - Fiyatın belirlenmesi } \\
\text { - Ödeme ve teslimat tarihlerinin belirlenmesi } \\
\text { - Siparişin kabulü }\end{array}$ \\
\hline ÜRETİM PLANLAMA (F2) & $\begin{array}{l}\text { - Alınan ve kabul edilen siparişe ait bilgilerin bilgi } \\
\text { işlem ortamına taşınması } \\
\text { - Sipariş ile ilgili madde ve malzemelerin tedariki } \\
\text { - Personel planlamasının yapılması } \\
\text { - Üretim emrinin verilmesi } \\
\end{array}$ \\
\hline ÜRETİM (F3) & $\begin{array}{l}\text { - Üretim emrinin kesim bölümüne ulaştırılması } \\
\text { - Üretim planına göre kesim işleminin yapılması } \\
\text { - Kesilen camların montaj bölümüne ulaştırılması } \\
\text { - Kesilen camlara göre alüminyum çıtaların kesilmesi } \\
\text { - Alüminyum çıtalara slica-gel maddesinin } \\
\text { doldurulması ve çıtaların birleştirilmesi } \\
\text { - Alüminyum çıtaların cama yapışmasını sağlayacak } \\
\text { butly ile kaplanması } \\
\text { - Camın, istenmeyen maddelerden arındırmak için saf } \\
\text { su ile yıkanması } \\
\text { - Butlyli çıtalar ile yıkanmış camın birleştirilmesi } \\
\text { - Birleştirilen camların (1sıcam) ilaçşama bölümüne } \\
\text { gönderilmesi } \\
\text { - Isıcamın kenarlarının poliüretan maddesi ile } \\
\text { kaplanması } \\
\text { - Poliüretanın kuruması ve ürünün hazır hale gelmesi }\end{array}$ \\
\hline TESLİMAT (F4) & $\begin{array}{l}\text { - Üretimi tamamlanan siparişin istenilen özellikler } \\
\text { açısından kontrolü } \\
\text { - Miktar kontrolü } \\
\text { - Kalite kontrolü } \\
\text { - Siparişin ambalajlanması } \\
\text { - Siparişin teslim edilmesi }\end{array}$ \\
\hline
\end{tabular}

Araştırmada FTM yöntemine göre öncelikle işletmede yapılan faaliyetler belirlenmiş sonrasında benzer faaliyetler aynı faaliyet merkezlerinde toplanmıştır. Tablo 2'den de anlaşılacağı üzere işletmenin faaliyetlerinden kaynaklanan çevresel maliyetler F3 üretim faaliyet merkezinde ortaya çıkmaktadır. 
Tablo 3: FTM Yöntemine Göre Maliyet Kaynakları

\begin{tabular}{|l|l|}
\hline Endirekt Gider Çeşitleri & Maliyet Kaynakları \\
\hline Endirekt İşçilik Giderleri & Üretim Personel Sayısı \\
\hline Çevresel Maliyetler & Üretim sayısı \\
\hline Su Giderleri & $\mathrm{M}^{2}$ \\
\hline Elektrik Giderleri & Öngörülen yüzdeler \\
\hline Amortisman & Makine sayısı \\
\hline
\end{tabular}

Tablo 3'te işletmenin FTM yöntemine göre dağıtımı yapılacak endirekt gider çeşitleri ve bunların dağıtımında kullanılacak dağıtım anahtarları (maliyet kaynakları) gösterilmektedir. Buna göre endirekt işçilik giderleri üretimde çalışan personel sayısına göre; çevresel maliyetler her bir birim ürünün üretilmesinden kaynaklandığı için üretim sayısına göre; su giderleri $\mathrm{m}^{2}$ 'ye göre; elektrik giderleri öngörülen yüzdelere göre ve amortisman giderleri faaliyet merkezlerinde kullanılan makine sayılarına göre dağıtılacaktır.

Tablo 4: Maliyet Kaynaklarının Faaliyet Merkezlerine Dağılımı

\begin{tabular}{|l|r|r|r|r|r|}
\hline $\begin{array}{c}\text { Faaliyet } \\
\text { Merkezleri }\end{array}$ & $\begin{array}{c}\text { Üretimde } \\
\text { Çalışan } \\
\text { Personel }\end{array}$ & $\begin{array}{c}\text { Üretim } \\
\text { Say1s1 }\end{array}$ & \multicolumn{1}{|c|}{$\mathrm{m}^{2}$} & $\begin{array}{c}\text { Öngörülen } \\
\text { Yüzdeler } \\
\text { (Elektrik) }\end{array}$ & $\begin{array}{c}\text { Makine } \\
\text { Say1s1 }\end{array}$ \\
\hline F1 & 3 & - & 48 & 2 & 1 \\
\hline F2 & 3 & - & 150 & 10 & 1 \\
\hline F3 & 45 & 110.000 & 5.500 & 78 & 10 \\
\hline F4 & 6 & - & 2.000 & 10 & 2 \\
\hline TOPLAM & 57 & 110.000 & 7.698 & 100 & 14 \\
\hline
\end{tabular}

Tablo 4'te maliyet kaynaklarının cam üretim işletmesi faaliyet merkezlerine dağılımı görülmektedir.

Tablo 5: Faaliyet Merkezlerine Ait Maliyet Toplamları

\begin{tabular}{|l|c|c|c|c|c|}
\hline $\begin{array}{c}\text { ENDİREKTGIDERLE } \\
\text { R }\end{array}$ & F1 & F2 & F3 & F4 & $\begin{array}{c}\text { TOPLA } \\
\text { M }\end{array}$ \\
\hline Endirekt İşçilik Giderleri & 5.526 & 5.526 & 82.895 & 11.053 & 105.000 \\
\hline Çevresel Maliyetler & - & - & 928.335 & - & 928.335 \\
\hline Su Giderleri & 750 & 2.340 & 85.734 & 31.176 & 120.000 \\
\hline Elektrik Giderleri & 6.400 & 32.000 & 249.600 & 32.000 & 320.000 \\
\hline Amortisman & 15.714 & 15.714 & 157.144 & 31.428 & 220.000 \\
\hline TOPLAM & $\mathbf{2 8 . 3 9 0}$ & $\mathbf{5 5 . 5 8 0}$ & $\begin{array}{r}\mathbf{1 . 5 0 3 . 7 0} \\
\mathbf{8}\end{array}$ & $\mathbf{1 0 5 . 6 5}$ & $\mathbf{1 . 6 9 3 . 3 3}$ \\
\hline
\end{tabular}


Tablo 5'te cam üretim işletmesinin endirekt giderleri ve bu giderlerin faaliyet merkezlerine dağılımı görülmektedir. FTM yöntemine göre, yöntemin ilk aşamasında F1 faaliyet merkezinde 28.390 TL, F2 faaliyet merkezinde 55.580 TL, F3 faaliyet merkezinde 1.503.708 TL ve F4 faaliyet merkezinde 105.657 TL olmak üzere toplam 1.693.335 TL dağıtılmıştır.

Tablo 6: Faaliyet Merkezlerinde Toplanan Maliyetlerin Ürünlere Yüklenmesi

\begin{tabular}{|c|c|c|c|c|c|}
\hline Faaliyet Merkezleri & F1 & F2 & F3 & F4 & TOPLAM \\
\hline Çevresel Maliyetler & - & - & 928.335 & _. & 928.335 \\
\hline Endirekt Maliyetler ${ }^{4}$ & 28.390 & 55.580 & 575.373 & 105.657 & 765.000 \\
\hline $\begin{array}{ll}\text { TOPLAM } & \text { ENDIREKT } \\
\text { MALIYET } & \\
\end{array}$ & 28.390 & 55.580 & 1.503.708 & 105.657 & 1.693 .335 \\
\hline $\begin{array}{ll}\text { BIRIM } & \text { ENDIREKT } \\
\text { MALIYET } & \\
\end{array}$ & 0,258 & $\mathbf{0 , 5 0 5}$ & 13,670 & 0,960 & 15,393 \\
\hline $\begin{array}{ll}\text { BIRIMM } & \text { ÇEVRESEL } \\
\text { MALIYET } & \\
\end{array}$ & & - & 8,439 & - & 8,439 \\
\hline
\end{tabular}

FTM yönteminin ikinci aşamasında faaliyet merkezlerinde toplanan maliyetler ürünlere yüklenmektedir. Bu aşamada faaliyet merkezlerinde toplanan maliyetler ürünlere üretim sayısı maliyet kaynağı (dağıtım anahtarı) kullanılarak yüklenmiştir. Tablo 6'da cam üretim işletmesinin endirekt giderleri ve endirekt giderler içerisinde değerlendirilen çevresel maliyetler ayrı ayrı gösterilmektedir. Buna göre F3 faaliyet merkezi dışında çevresel maliyet oluşmamıştır. F3 faaliyet merkezi toplam maliyeti olan 1.503.708TL'nin 928.335 TL'si çevresel maliyetlerdir. İşletmenin birim endirekt maliyeti 15,393 TL ve bunun 8, 439 TL'si çevresel maliyettir.

\section{SONUÇ}

Küreselleşme, teknolojik gelişmeler, dünya nüfusunun ve buna paralel olarak üretim ve tüketimin hızla artması, savaşlar, kazalar vb. çevre sorunlarının artmasına ve serbest mal olarak görülen çevrenin artık sınırlı bir kaynak olarak görülmesine neden olmuştur. Çevre ve çevre ile ilgili kaynakların işletmelerin üretim girdilerini oluşturması ve işletmelerin faaliyetleri sonucu birtakım atıkların oluşması çevresel sorunların artmasıyla sonuçlanmış ve çevre sorunlarına çözüm yolları aranmaya başlanmıştır. Bunlardan biri de temel amacı olumsuz çevresel etkileri azaltmak, çevresel maliyetleri doğru belirlemek ve minimize etmek olan çevre muhasebesidir.

Çalışmanın uygulaması, Akdeniz Bölgesinde faaliyet gösteren büyük ölçekli bir ısıcam üretim işletmesinde gerçekleştirilmiştir.

Çevresel maliyetler, endirekt karakterli olarak da oluşabildiği için çalışmada genel üretim gideri boyutunda ele alınmıştır. Çevresel maliyetlerin genel üretim giderleri içerisinde belirlenmesinde ise geleneksel maliyet yöntemleri yerine faaliyet tabanlı maliyetleme yöntemi kullanılmıştır.

${ }^{4}$ Çevresel maliyetleri genel üretim giderlerinin içinde değil ayrıca üst satırda değerlendirilmiştir. 
Uygulamada çevresel maliyetler, FTM yöntemi ile ayrı bir unsur olarak sınıflandırılmış ve neden sonuç ilişkisi kurularak çıkış noktalarına göre net bir şekilde belirlenebilmiştir. Elde edilen sonuçlara göre işletmenin 1.503.708 TL genel üretim giderlerinin 928.335 TL'si baca filtrelerinin temizliği, cam temizleme sonucu suyun kirlenmesi nedeniyle ödenen vergiler, endirekt madde olarak kullanılan kimyasalların giderleri gibi çevresel maliyetlerdir ve bu maliyetler işletmenin üretim faaliyet merkezinde (F3) ortaya çıkmıştır.

İşletmenin çevresel maliyetleri FTM yöntemi ile ürünlere daha doğru yüklenebilmiş ve toplam ve birim maliyetlerdeki ağırlığı net bir şekilde belirlenebilmiştir. Buna göre işletmenin birim endirekt maliyeti olan 15,393 TL'nin \%54'ü diğer bir deyişle 8,439 TL'si çevresel maliyetlerden oluşmaktadır.

Çevresel maliyetlerin, FTM yöntemi ile belirlenmesi, bu maliyetlerin üretim faaliyetlerinin hangi aşamasında ortaya çıtığının belirlenmesine olanak sağlamıştır. Yöntemle, çevresel maliyetlerin genel üretim giderleri içerisinde ayrı bir unsur olarak alınması ve daha anlamlı dağıtım anahtarları (maliyet kaynakları) kullanılarak ürünlere yüklenmesi çevresel maliyetlerin hem toplam hem de birim olarak görülmesine olanak sağlamıştır.

Çevresel maliyetlerin işletmenin toplam giderleri içerisinde sınıflandırılması, üretimin hangi aşamasında ve hangi faaliyetlerden ortaya çıktığının belirlenmesi maliyet etkinliği açısından büyük önem taşımaktadır. Uygulama yapılan işletmede de görüldüğü üzere çevreden nispeten daha fazla yararlanan işletmelerin çevresel maliyetleri, toplam endirekt maliyetler içerisinde büyük bir paya sahip olabilmektedir. Bu nedenle işletmelerin maliyetlerini kontrol altına alarak azaltabilmeleri çevresel maliyetlerin doğru bir şekilde belirlemelerine bağlıdır.

Çevresel maliyetler doğru bir şekilde belirlenirse, işletmelerin faaliyetleri nedeniyle oluşan çevre kirliliği sebebiyle katlandıkları önleme maliyetleri ve hava, su, toprak vb. kullanımlarından kaynaklanan kullanma maliyetleri iyileştirilerek çevreye verdikleri zararlardan kaynaklanan ve ölçülemeyen zarar maliyetleri azaltılabilir ve/veya ortadan kaldırılabilir.

FTM yöntemiyle çevresel maliyetler içinde değer yaratmayan faaliyetlerin maliyet unsurlarının ortadan kaldırılmasıyla maliyet etkinliği sağlanabilecektir. Değer yaratmayan faaliyetlerin maliyetlerinin ortadan kaldırılması, dolaylı olarak direkt işçilik ve endirekt işçilik boyutunda da maliyet minimizasyonuna katkı sağlayabilecektir. Özetle, yoğun rekabet ortamında fiyat belirleyememe sorunsalı nedeniyle "fiyat $=$ maliyet + kar" denklemi noktasında maliyetlerin azaltılmas hissedarlara daha yüksek kar ya da maliyet avantajı kadar fiyat indirme olanağ 1 sağlayabilecektir.

Çevresel maliyetlerin FTM ile belirlenmesine yönelik çalışmaların yok denecek kadar az olması bu çalışmanın yapılmasında büyük bir etken olmuştur. Gelecekte çevresel maliyetlerin diğer maliyet yöntemleri ile entegre edilerek farklı sektörlerde çalışmalar yapılmasının ilgili literatüre katkı sağlayacağı düşünülmektedir. 


\section{KAYNAKÇA}

Alagöz, M. (2012). Konaklama İşletmelerinde Çevre Muhasebesi Uygulamaları: Marmaris İlçesi Örneği. (Yayınlanmamış Yüksek Lisans Tezi). Muğla Sitkı Kocaman Üniversitesi Sosyal Bilimler Enstitüsü, Muğla.

Aydın, S. (2012). Paydaşların Çevre Muhasebesi Uygulamalarına Etkileri. Muhasebe ve Denetime Bakış, Nisan, 99-107.

Bakkal, A. (2014). Çevre Muhasebesi Uygulamalarının Bilecik Işsletmelerinde Uygulanması Üzerine Bir Çalışma. (Yayınlanmamış Yüksek Lisans Tezi). Bilecik Üniversitesi Sosyal Bilimler Enstitüsü, Bilecik.

Barth, M., Livet, A., Guio, R. (2008). Effective Activity-Based Costing For Manufacturing Enterprises Using A Shop Floor Reference Model. International Journal of Production Research. 46 (3): 621 - 646.

Başkale, E. (2009). Çevre Muhasebesi ve Uygulaması. (Yayınlanmamış Yüksek Lisans Tezi). Marmara Üniversitesi Sosyal Bilimler Enstitüsü, İstanbul.

Beer, P., Friend, F. (2006). Environmental Accounting: A Management Tool for Enhancing Corporate Environmental and Economic Performance. Ecological Economics, (58):548-560. doi:10.1016/j.ecolecon.2005.07.026.

Çalış, Y.E. (2013). Çevresel Maliyetlerin Muhasebeleştirilmesi. Marmara Üniversitesi I.I.I.B.F. Dergisi, 34 (1): 175-190.

Çelik, M. (2007). Çevreye Duyarlı Muhasebe. Muhasebe ve Finansman Dergisi, (33):151-161.

Çetin, E. (2011). Üretim İşletmelerinin Sosyal Bir Sorumluluk Olarak Çevre Muhasebesine Verdikleri Önem: Mersin-Tarsus Organize Sanayi Bölgesinde Faaliyet Gösteren Üretim İşletmeleri Üzerine Bir Uygulama. (Yayınlanmamış Yüksek Lisans Tezi). Karamanoğlu Mehmetbey Üniversitesi Sosyal Bilimler Enstitüsü, Karaman.

Çetin, A.T., Özcan, M., Yücel, R. (2004). Çevre Muhasebesine Genel Bakış. SÜ İIBF Sosyal ve Ekonomik Araştırmalar Dergisi, 4, (7):61-76.

Eagan, P.D., Joere, E. (2002). The Utility Of Environmental Impact Information: A Manufacturing Case Study. Journal of Cleaner Production, 10, 75-83.

EPA (Environmental Protection Agency). (1995). "An Introduction to Environmental Accounting as a Business Management Tool" Washington.

Erden, S.A. (2004). Üretim Ortamları Maliyet Yönetim Sistemleri İlişkisi ve Stratejik Maliyet Yönetimi, İstanbul: Türkmen Kitabevi.

Ergin, H., Okutmuş, E. (2007). Çevre Muhasebesi: Çevre Maliyetleri ve Çevre Raporlaması. Yönetim Bilimleri Dergisi, 5(1): 144-180.

Ergül, A. (2014). Hedef Maliyetleme Çerçevesinde Çă̆daş Maliyet Yöntemlerinin Maliyet Etkinliği Boyutunda Entegrasyonu ve Konaklama İşletmelerinde Uygulanması. (Yayınlanmamış Doktora Tezi). Akdeniz Üniversitesi Sosyal Bilimler Enstitüsü, Antalya.

Gale, R. (2006). Environmental Management Accounting As A Reflexive Modernization Strategy In Cleaner Production. Journal Of Cleaner Production, (14): 1228-1236. doi:10.1016/j.jclepro.2005.08.008.

Gönen, S., Güven, Z. (2014). Çevresel Maliyetlerin Muhasebeleştirilmesine Yönelik Bir Seramik Fabrikasinda Uygulama. Muhasebe ve Finans Dergisi, Temmuz: 39-58.

Hacırüstemoğlu, R. (1995). Maliyet Muhasebesi, İstanbul: Dizgi-Bask1-Cilt Ders Kitapları A.Ş. Tesisleri.

Haftac1, V., Soylu K. (2007). Çevre Kirlenmesi ve Çevre Koruma Bağlamında Çevre Muhasebesinin Önemi. Muhasebe ve Finans Dergisi, (33): 102-120.

Haftacı, V., Soylu K. (2008). Çevresel Bilgilerin Muhasebesi ve Raporlanması. Kocaeli Üniversitesi Sosyal Bilimler Enstitüsü Dergisi, 15 (1): 92-113.

Hiçyorulmaz, E. (2015). Çevre Muhasebesi ve Çimento Fabrikalarının Çevre Muhasebesine Olan Duyarlılığı: Çorum Votorantim Çimento Fabrikası Uygulaması. (Yayınlanmamış Yüksek LisansTezi). Hitit Üniversitesi Sosyal Bilimler Enstitüsü, Çorum.

Jachnick, R. (2006). Assessing The Practical Relevancy Of Environmental Cost Accounting For Industrial Waste. Master of Science in Environmental Management and Policy Lund, Sweden. 
Jasch, C. (2003). The Use Of Environmental Management Accounting (EMA) For Identifying Environmental Costs. Journal of Cleaner Production, (11): 667-676. doi:10.1016/S09596526(02)00107-5.

Kılıç, E. (2008). Türkiye Konaklama Işsletmelerinde Çevre Muhasebesi ve AB Uygulamalarlyla Karşılaştırılması: Antalya Bölgesinde Bir Araştırma. (Yayınlanmamış Yüksek Lisans Tezi). Akdeniz Üniversitesi Sosyal Bilimler Enstitüsü, Antalya.

Kırlıoğlu, H., Can, A.V. (2006). Çevresel Muhasebede Kavramsal Tartışmaların Gelişimi ve Analizi. Muhasebe ve Finans Dünyası Dergisi, (10): 1-12.

Kırlıoğlu, H., Fidan, M.E. (2010). Organize Sanayi Bölgeleri İçinde ve Dışında Faaliyet Gösteren İşletmelerin Çevre - Atık Yönetimi Muhasebesi Konularında Mevcut Durum ve Farklılıkları (Sakarya İlinde Bir Araştırma). Muhasebe ve Denetime Bakış, Ekim: 1-28.

Kırlıoğlu, H., Fidan, M.E. (2011). İşletmelerde Çevresel Maliyetler ve Bir Uygulama. Akademik Yaklaşımlar Dergisi, 2 (1): 1-24.

Kırlığlu, H., Yıldız, ŞK. (2004). Belediyelerde Çevre Muhasebesi Uygulaması. Muhasebe ve Finans Dergisi, (22): 49-60.

Kırlıoğlu, H., Zeytin, M. (2015). Belediyelerde Çevre Muhasebesi ve Raporlama: Marmara Bölgesinde Bulunan Belediyeler Üzerine Bir Durum Analizi. Akademik Sosyal Araştırmalar Dergisi, 3 (10): 753-777.

Lazol, İ., Muğal, E., Yücel, Y. (2008). Sürdürülebilir Bir Çevre İçin Çevre Muhasebesi ve KOBİ'lere Yönelik Bir Araştırma. Muhasebe ve Finans Dergisi, 56-69.

Letmathe, P., Doost, R.K. (2000). Environmental Cost Accounting And Auditing. MAnagerial Auditing Journal, 15 (8): 424-430.

Okutmuş, E. (2005). Çevre Muhasebesi ve Bir Uygulama. (Yayınlanmamış Doktora Tezi). Afyon Kocatepe Üniversitesi Sosyal Bilimler Enstitüsü, Afyon.

Tuğlu, U. (2010). Çevre Muhasebesi ve Alanya'daki Bir Konaklama Işsletmesinde Uygulaması. (Yayınlanmamış Yüksek Lisans Tezi). Akdeniz Üniversitesi Sosyal bilimler Enstitüsü, Antalya.

Wegmann, G. (2009). The Activity-Based Costing Method: Development And Applications. The Icfai University Journal of Accounting Research, 8 (1): 7 - 22.

Yereli, A. N., Yakın, V. (2009). Çevresel Yönetim Muhasebesi Aracı Olarak Malzeme Akış Maliyet Muhasebesi Yöntemi. Muhasebe ve Denetime Bakış, Ocak: 69-90.

\section{SUMMARY}

Global competition, population growth, rapid increase in production and consumption, product development and renewal requirement, excessive consumption, wars, accidents etc. has brought environmental concerns. Previously, the environment was seen as free good, began to be seen as an economic good with the increase of environmental problems. In addition to all these, public pressure, the reaction of consumers, legal regulations related to the environment and various organizations posed to be to the businesses more sensitive about the environment and to use impact of the results of the businesses operations in the decision-making process. Excessive use of the environment, when exceeded self-renewal capacity have emerged environmental problems. Envviromental problems that continuing increase since 1970's has reached threatens to live life and has become important causes and solutions of the environmental problems. One of these methods is environmental accounting. Its main function is to minimize the environmental cost, to reduce the negative environmental impacts and to provide the environmental cost informations to the management in decision-making process. 
The enterprises are required to charge correctly environmental costs to the products by establishing cause and effect relationships fort the purpose of reducing the environmental demage and environmental costs. But, the charge envitonmental costs to the products with the traditional cost accounting methods caused not to see the negative effects clearly in the production prosesses. It also will not contribute the decision-making process of the management. That's why the environmental costs should be invastigate with the modern cost accounting methods to measure accurately and minimize. One of the modern cost accounting methods that can be used together with the environmental cost accounting is activity based costing method.The combination of the two methods will provide environmental costs which stage of the production arising and determining what activities caused by these costs.

The purpose of this study, is to determine and minimize the environmental costs and to eliminate and / or to reduce the negative effects on the environment of businesses that more benefit and more negative effects on environment. For this purpose, was conducted field research In an insulating glass production companies operating in the Mediterranean Region.

The study consisted of four sections. In the first chapter has been examined in detail the concept of environmental accounting. In the secont section is located environmental costs and classification of the cost. In the third section were examined together environmental costs and activity-based costing. The fourth chapter is devoted to the application of the study findings. 